\title{
Food Security and Trade in Food Products in Nigeria
}

\author{
Nahanga Verter $^{1}$
}

\begin{abstract}
Improving food security depends on identifying the indicators of food insecurity that must be monitored and addressed by the policy makers and implementers. This paper investigates the dynamics of trade in food products and food security in Nigeria. Using descriptive approaches, the findings show that Nigeria markedly recorded an adverse TBI in total agri-food trade and many food products. Remarkably, the five mostly exported (i.e. cocoa, fruits and nuts, oilseeds, tobacco) and five mostly imported (wheat, edible products, fish, sugar, milk and cream) food products accounted for $78 \%$ and $70 \%$ of total food exports and imports in the country. The study also reveals that Nigeria has been grossly food insecure driven by indicators, such as infrastructure deficit, population growth, poverty, corruption, inadequate government support to farmers and absence of safety net programmes. The Nigerian government and other stakeholders should holistically invest and implement agricultural policies to improve food security and earnings in many food products.
\end{abstract}

Keywords: accessibility, affordability, availability, food insecurity, poverty, TBI

\section{Introduction}

Food security 'exists when all people, at all times, have physical, social and economic access to sufficient, safe and nutritious food that meets their dietary needs and food preferences for an active and healthy life' (World Food Summit, 1996). On the other hand, food insecurity 'exists when people lack secure access to sufficient amounts of safe and nutritious food for normal growth and development and an active and healthy life'. This might be occasioned by unavailability of food, insufficient purchasing power, inadequate use of food or inappropriate distribution channels at the household level. Food insecurity in a country or region may be chronic, seasonal or transitory (FAO et al., 2018).

One of the significant challenges of the 21 st century is to ensure that the world population has sustainable access to adequate, affordable and nutritious food sufficient to eliminate hunger (World Food Summit, 1996), especially in developing countries like Nigeria. For instance, in 2018, more than 113 million people in 53 countries witnessed acute hunger that required urgent food, nutrition and livelihoods support. In order of severity, Yemen, DR Congo, Afghanistan, Ethiopia, Syria, Sudan, South Sudan and northern Nigeria were the worst food crises in 2018 (FSIN, 2019).

Tackling the challenges of malnutrition, hunger and food insecurity in all its forms have prominently been featured in the UN Sustainable Development Goal (SDGs) of the 2030 Agenda. Similarly, SDG2 aimed at ensuring zero hunger, achieving food security and promoting sustainable agriculture in countries. Thus, ensuring access to nutritious, safe and enough food for all (Target 2.1) and eliminating all forms of malnutrition (Target 2.2) among other targets were set in SDG2. It also understood that attainment of SDG2 
substantially relies on other goals, such as ending poverty (SDG1), improving health and wellbeing (SDG3), and addressing the effects of climate change (SDG13) in countries (FAO et al., 2018).

Ending hunger and attaining food security may be strenuous to achieve in developing countries, such as Nigeria that have experienced financial turmoil and political shocks (de Sousa et al., 2019). Recently, the Northeast and some parts of the northcentral parts of Nigeria have been characterised by chronic food insecurity driven by the clashes between local farmers and cattle herders (World Food Programme, 2019), low-level of food production (FAO et al., 2018) relative to population growth (UN DESA, 2019).

Food production in Nigeria has faced severe obstacles, such as adverse climate shocks, unpredictable rainfall (Adebayo \& Ojo, 2012), lack of modern farm inputs and technologies, government neglect and lack of policy directions (Verter, 2016; MBNP, 2017; FAO el at., 2018). These constraints, coupled with other impediments, have nullified Nigeria's capacity to achieve food self-sufficiency (UNCTAD, 2019; FSIN, 2019). Consequently, Nigeria has substantially dependent on advanced and emerging economies for processed food products (Adebayo \& Ojo, 2012), as postulated by dependency theories (Verter, 2016). Free trade in food trade and over-reliant on food imports have been arguably accused of being among the principal causes of undernutrition and food insecurity in developing countries. They argue that some developing countries are well developed to take advantage of agrarian free trade (Singh, 2014; Verter, 2016; Mary, 2019). For instance, studies by Mary (2019) suggests that the over-reliant on food imports and food trade openness may increase the prevalence of undernourishment, hunger in developing countries (Nigeria included). Mary argues that Nigeria and some other developing countries would be better off adopting food self-sufficiency measures at least in the short run, even if such actions are at variance with the WTO's regulations.

To reduce food insecurity in Nigeria, the federal launched an economic policy document, 'Economic Recovery and Growth Plan (ERGP)' in 2017 to ensure self-sufficiency in food products, such as tomato paste, rice and sugar by 2019/2020. Thus, Nigeria plans to deepen investments in the food value chain, especially in critical products, such as rice, cassava, peanuts, cashew nuts, milk and cream by 2020 (MBNP, 2017).

The ERGP was developed from the agricultural policies, such as the 'Agricultural Transformation Agenda (ATA)', and the 'Agriculture Promotion Policy (APP)', also known as the 'Green Alternative Policy,' launched in 2015, covered for the period 2016-2020 (FMARD, 2016). Both the ATA and APP policies were launched to attract investments in food production, enhance farmers access to finance and markets, reduce post-harvest losses, boost value chain, ensure food self-sufficiency in critical food products (MBNP, 2017). In 2016, the federal government of Nigeria scaled up the "Home-Grown School-Feeding" (HGSF) to feed primary school children and improve their enrolment, and partially reduce hunger and starvation of the pupils in public schools. The HGSF initiative provides free school meals procured and prepared by local farmers (FAO, 2017). In the same direction, in 2017, the Nigerian government presented a ten-year (spans 2016-2025) food security and nutrition strategy. The strategy includes sensitive nutrition interventions in agriculture, education and social protection, and the provision of domestically processed nutritious foods to children and pregnant and lactating women and girls (World Food Programme, 2019). 
In line with the UN SDG17, FAO has unveiled a 5-year strategic plan (2018-2022) to boost natural resources management and sustainable agriculture in Nigeria. Based on Nigeria's on the ERGP and agricultural policies, FAO welcomed the development and humanitarian needs of the country in priority areas: strengthening national food and nutrition security via augmented climate-smart food systems and nutrition sensitive. Although some studies have assessed food security issues (Omonona \& Agoi, 2007; Verma et al., 2019; Plaisier et al., 2019; Lamidi, 2019) and agricultural trade in Nigeria (Verter, 2016; Mary, 2019), to the best of my knowledge, no study has simultaneously investigated the dynamics of trade in agri-food products and food security indicators in the country. Thus, this study bridges the gap.

\section{Methodology}

This paper assesses the dynamics of agri-food trade and food security indicators in Nigeria. The data for the study are obtained from the UN Conference on Trade and Development (UNCTAD), Food and Agriculture Organization of the United Nations (FAO), and the Economist Intelligence Unit (EIU). The classification of food product groups assessed in this paper is culled from UNCTAD following the UN Standard International Trade Classification (SITC, Revision 3). The indicators are calculated (current prices, US\$) at the three-digit level of the SITC for all the 46 food product groups $($ SITC $0+1+22+4) \cdot{ }^{1}$

In investigating trade performance in agri-food products, it is understandable to assess trade specialisation. Thus, the Trade Balance Index (TBI) is used to determine whether a given country is a net-exporter or net-importer for a product or total products. TBI is mathematically formulated as follows:

$T B I_{j}^{i}=\frac{x_{j}^{i}-m_{j}^{i}}{x_{j}^{i}+m_{j}^{i}}$

Where; $T B I_{i j}$ denotes trade balance index of country $i$ for product $j ; x_{i j}$ and $m_{i j}$ represent exports and imports of product products $j$ by nation $i$, respectively. The values of the index range from -1 to +1 . The TBI equals +1 if a nation only exports. Inversely, the TBI equals -1 if a nation only imports. Undoubtedly, the index is not defined if the nation neither exports nor imports a given product. The nation is referred to as a net-exporter (net importer) of a food product if the value of TBI is positive (negative).

${ }^{1}$ The UN SITC (revision 3, 3-digit code) for the 46 food items are as follows: SITC 001 (Live animals); SITC 011 (Bovine Meat); SITC 012 (Other meat, other offal); SITC 016 (Meat, ed. offl., dry, slt, smk); SITC 017 (Meat, offl. Prdd, nes); SITC 022 (Milk and cream); SITC 023 (Butter, other fat of milk); SITC 024 (Cheese and curd); SITC 025 (Eggs, birds, yolks, albumin); SITC 034 (Fish, fresh, chilled, frozen); SITC 035 (Fish, dried, salted, smoked); SITC 036 (Crustaceans, Molluscs); SITC 037 (Fish etc. prepd, prsvd. Nes); SITC 041 (Wheat, Meslin, Unmilled); SITC 042 (Rice); SITC 043 (Barley, unmilled); SITC 044 (Maize unmilled); SITC 045 (Other cereals, unmilled); SITC 46 (Meal, Flour of wheat, msln); SITC 047 (Other cereal meal, flours); SITC 048 (Cereal preparations); SITC 054 (Vegetables); SITC 056 (Vegetables, prpd, prsvd, nes); SITC 057 (Fruit, nuts excl. oil nuts); SITC 058 (Fruit, preserved, prepared); SITC 059 (Fruit, vegetable juices); SITC 061 (Sugars, molasses, honey); SITC 062 (Sugar, confectionery); SITC 022 (Milk and cream); SITC 071 (Coffee, coffee substitutes); SITC 072 (Cocoa); SITC 073 (Chocolate, oth. cocoa prep.); SITC 074 (Tea and mate); SITC 075 (Spices); SITC 081 (Animal feed stuff); SITC 091 (Margarine and shorten); SITC 098 (Edible prod. prepetns, nes); SITC 111 (Non-alcohol. Beverage); SITC 112 (Alcoholic Beverages); SITC 121 (Tobacco, unmanufactured); SITC 122 (Tobacco, manufactured); SITC 222 (Oil seeds and oleaginous fruits (excl. flour)); SITC 223 (Oil seeds, oleaginous fruits (incl. flour, n.e.s.)); SITC 411 (Animal oils and fats); SITC 421 (Fixed veg. fat, oils, soft); SITC 422 (Fixed veg. fat, oils, other); and SITC 431 (Animal, veg. Fats, oils, nes.) 
The Global Food Security Index (GFSI) as presented by the EIU, considers the core issues of food availability, affordability, and quality and safety in 113 countries. In this study, Nigeria is chosen and compared with Sub-Saharan Africa (SSA) and the average performance of the 113 countries (referred to as the world) as calculated by the EIU. The index serves as a dynamic quantitative benchmarking model, that is constructed from unparalleled indicators which measure the drivers of food security/insecurity in countries. The findings are presented in scores and rank. The scores range from 0-100 (where $100=$ best). The values close to 0 indicates that the indicator has an issue and is a constraint to food security attainment. Given that some countries in the world are not included in the GFSI, this study emphasises on the scores more than the rankings. This is because the score is a country-specific; it shades more light on the state of food security/insecurity than the ranking.

Remarkably, the index also includes an indicator that assesses individual country's' exposure to the effects of climate shocks; their susceptibility to natural resource risks; and how nations have adapted to these prevailing shocks. Given that socioeconomic and environmental indicators in Nigeria has faced challenges, it relevant to assess the country's food status as calculated by the EIU.

\section{Results and discussion}

\subsection{Trade in Food Products Between Nigeria and the World}

The value of total agri-food exports (SITC $0+1+22+4$ ) in Nigeria rose from $\$ 2.37$ billion in 2012 to $\$ 2.42$ billion in 2013 and then decreased to $\$ 1.15$ billion in 2016 , before slightly increasing to $\$ 1.45$ billion in 2017 . Sadly, Nigeria marginally witnessed negative trade balance and trade balance index (TBI) in the overall agri-food trade (Table 1). It suggests that the country is a consuming nation as imports substantially outweigh exports.

Table 1: Dynamics of total food trade (SITC 0+1+22+4) in Nigeria, 2012-2017

\begin{tabular}{lllllll}
\hline Indicator/year & 2012 & 2013 & 2014 & 2015 & 2016 & 2017 \\
\hline Number of product groups & 46 & 46 & 46 & 46 & 46 & 46 \\
Exports (Millions, US\$) & 2,370 & 2,421 & 1,772 & 1,794 & 1,147 & 1,445 \\
Imports (Millions, US\$) & 9,057 & 7,994 & 8,769 & 6,639 & 4,391 & 6,120 \\
Balance (Millions, US\$) & - & $-5,573$ & - & - & $-3,244$ & - \\
& 6,687 & & 6,997 & 4,846 & & 4,675 \\
TBI (index) & -0.59 & -0.54 & -0.66 & -0.57 & -0.59 & -0.62 \\
\hline Top 10 export products (\% of total food & 78.85 & 86.71 & 92.17 & 85.81 & 94.94 & 92.29 \\
exports) & & & & & & \\
[072] Cocoa & 41.82 & 47.53 & 47.61 & 46.64 & 43.01 & 35.57 \\
[057] Fruits and nuts (exc. oil nuts) & 8.44 & 7.68 & 7.89 & 8.40 & 15.80 & 15.83 \\
[222] Oil seeds and oleaginous & 11.03 & 16.01 & 20.02 & 14.56 & 15.94 & 15.74 \\
[122] Tobacco, manufactured & 4.30 & 3.61 & 4.27 & 4.70 & 6.10 & 6.55 \\
[036] Crustaceans, mollscs, etc & 4.10 & 4.49 & 4.41 & 4.16 & 5.99 & 4.50 \\
[098] Edible products and prep. & 1.07 & 2.11 & 2.77 & 1.73 & 1.67 & 3.97 \\
[223] Oil seeds \& oleaginous & 0.02 & 0.41 & 0.14 & 0.28 & 0.66 & 3.22 \\
[075] Spices & 2.63 & 2.41 & 2.92 & 3.15 & 2.77 & 2.54 \\
[081] Feeding stuff for animals & 4.98 & 1.52 & 1.50 & 1.51 & 2.35 & 2.51 \\
[111] Non-alcoholic beverages & 0.46 & 0.96 & 0.63 & 0.69 & 0.65 & 1.86 \\
\hline
\end{tabular}




\begin{tabular}{lllllll}
\hline $\begin{array}{l}\text { Top 10 import products (\% of total food } \\
\text { imports) }\end{array}$ & 64.36 & 75.38 & 75.69 & 71.49 & 81.40 & 83.03 \\
[041] Wheat (incl. spelt), etc & 20.73 & 23.68 & 22.98 & 24.06 & 24.99 & 26.41 \\
[098] Edible products and prep. & 6.96 & 12.75 & 9.46 & 9.68 & 10.68 & 12.70 \\
[034] Fish, fresh (live or dead) & 13.89 & 12.86 & 12.74 & 19.13 & 11.12 & 11.68 \\
[061] Sugar, molasses/ honey & 8.82 & 9.62 & 9.22 & 3.85 & 13.77 & 11.28 \\
[022] Milk and cream & 6.31 & 7.13 & 9.14 & 5.07 & 7.43 & 7.98 \\
[422] Fixed vegetable fats, etc & 2.29 & 3.11 & 5.78 & 3.29 & 5.46 & 4.14 \\
[044] Maize (not incl. sweet & 0.22 & 0.62 & 0.59 & 0.19 & 1.20 & 2.57 \\
[121] Tobacco, unman & 0.99 & 1.32 & 1.15 & 1.39 & 2.10 & 2.27 \\
[048] Cereal preparations, etc & 1.72 & 1.97 & 2.13 & 2.22 & 2.23 & 2.07 \\
[035] Fish, dried, salted/brine & 2.43 & 2.33 & 2.49 & 2.62 & 2.40 & 1.94 \\
\hline
\end{tabular}

Source: Own composition based on UNCTAD (2019)

It is important to restate that Nigeria's employment in agriculture ( $\%$ of total employment) accounted for an average of 37.5\% between 2012 and 2018 (World Bank, 2019). Notwithstanding, the country has been a net importer of food. The question is, why? Arguably, low value-added in the food value chains occasioned by lack of modern farm inputs and technologies, and government neglect has contributed to low productivity (FSIN, 2019) and excessive reliance on food imports to fill the domestic supply gaps (Verter, 2016). It is worth reiterating that food imports may fill the domestic supply gaps and bring a wide variety of choices to consumers on the one hand. On the other hand, it may also be detrimental to domestic rural farmers that substantially rely on agriculture as a source of income and overall livelihoods, including food security. For instance, studies by Mary (2019) show that agri-food trade openness may increase the prevalence of undernourishment in some developing countries such as Nigeria.

Table 2: TBI (index) in 46 food product groups (SITC 0+1+22+4) in Nigeria, 2012-2017

\begin{tabular}{|c|c|c|c|c|c|c|}
\hline SITC code/Year & 2012 & 2013 & 2014 & 2015 & 2016 & 2017 \\
\hline [001] Live animals other than animals of division & - & - & - & 0.08 & - & - \\
\hline 03 & 0.34 & 0.91 & 0.97 & & 0.96 & 0.91 \\
\hline \multirow{4}{*}{$\begin{array}{l}\text { [011] Meat of bovine animals, fresh, chilled or } \\
\text { frozen } \\
\text { [012] Other meat and edible meat offal }\end{array}$} & - & - & - & - & - & - \\
\hline & 1.00 & 0.98 & 1.00 & 0.99 & 0.95 & 0.60 \\
\hline & - & - & - & - & - & - \\
\hline & 0.88 & 0.87 & 0.72 & 0.80 & 0.85 & 0.99 \\
\hline \multirow{2}{*}{$\begin{array}{l}\text { [016] Meat, edible meat offal, salted, dried; flours, } \\
\text { meals }\end{array}$} & 0.35 & - & - & - & - & - \\
\hline & & 0.99 & 0.64 & 0.16 & 0.62 & 0.80 \\
\hline \multirow{2}{*}{$\begin{array}{l}\text { [017] Meat, edible meat offal, prepared, preserved, } \\
\text { n.e.s. }\end{array}$} & - & - & - & - & - & - \\
\hline & 1.00 & 0.60 & 0.85 & 0.74 & 1.00 & 0.81 \\
\hline \multirow{2}{*}{$\begin{array}{l}\text { [022] Milk, cream and milk products (exc. butter, } \\
\text { cheese) }\end{array}$} & - & - & - & - & - & - \\
\hline & 0.20 & 0.71 & 0.93 & 0.46 & 0.97 & 0.94 \\
\hline \multirow{2}{*}{$\begin{array}{l}\text { [023] Butter and other fats and oils derived from } \\
\text { milk }\end{array}$} & - & - & - & - & - & - \\
\hline & 0.99 & 0.83 & 0.99 & 0.90 & 1.00 & 1.00 \\
\hline \multirow[t]{2}{*}{ [024] Cheese and curd } & - & - & - & - & - & - \\
\hline & 1.00 & 0.98 & 1.00 & 0.98 & 1.00 & 1.00 \\
\hline \multirow[t]{2}{*}{ [025] Birds' eggs, and eggs' yolks; egg albumin } & - & - & - & - & - & - \\
\hline & 0.99 & 0.88 & 1.00 & 0.98 & 0.96 & 0.99 \\
\hline \multirow[t]{2}{*}{ [034] Fish, fresh (live or dead), chilled or frozen } & - & - & - & - & - & - \\
\hline & 1.00 & 0.96 & 1.00 & 0.99 & 1.00 & 1.00 \\
\hline
\end{tabular}


[035] Fish, dried, salted or in brine; smoked fish

[036] Crustaceans, mollusks and aquatic $\begin{array}{lllllll}1.00 & 0.96 & 0.94 & 1.00 & 0.99 & 0.99 & 0.98 \\ 0.97 & 0.82 & 0.96 & 0.90\end{array}$ invertebrates

[037] Fish, aqua. invertebrates, prepared, preserved, n.e.s.

$\begin{array}{llllll}1.00 & 0.99 & 1.00 & 0.99 & 0.98 & 0.81\end{array}$

[041] Wheat (including spelt) and meslin, unmilled

[042] Rice

[043] Barley, unmilled

$\begin{array}{llllll}1.00 & 0.94 & 1.00 & 0.97 & 1.00 & 1.00\end{array}$

$\begin{array}{llllll}1.00 & 0.95 & 1.00 & 1.00 & 1.00 & 0.99\end{array}$

$\begin{array}{llllll}- & - & - & - & - & - \\ 1.00 & 0.98 & 1.00 & 1.00 & 1.00 & 1.00\end{array}$

[044] Maize (not including sweet corn), unmilled

[045] Cereals, unmilled (exc. wheat, rice, barley, maize)

$\begin{array}{llllll}- & - & - & - & - & - \\ 0.93 & 0.83 & 1.00 & 0.66 & 1.00 & 1.00\end{array}$

[046] Meal and flour of wheat and flour of meslin

0.94

$-$

$\begin{array}{lllll}0.36 & 0.95 & 0.27 & 0.97 & 0.99\end{array}$

$\begin{array}{llllll}- & - & 0.26 & - & - & - \\ 0.31 & 0.31 & & 0.61 & 0.80 & 0.72\end{array}$

[047] Other cereal meals and flour

$\begin{array}{llllll}- & - & - & - & - & - \\ 0.98 & 0.81 & 0.96 & 0.86 & 0.94 & 0.93\end{array}$

[048] Cereal preparations, flour of fruits or vegetables

$-$

[054] Vegetables

0.93

0.02

$\begin{array}{lllll}- & - & - & - & - \\ 0.94 & 0.96 & 0.96 & 0.96 & 0.76\end{array}$

[056] Vegetables, roots, tubers, prepared, preserved, n.e.s.

$\begin{array}{llllll}0.96 & 0.90 & 0.98 & 0.97 & 0.97 & 0.96\end{array}$

[057] Fruits and nuts (excluding oil nuts), fresh or

0.81

0.19

0.25

0.37

0.54

0.49

dried

[058] Fruit, preserved, and fruit preparations (no juice) spirit

$\begin{array}{lllll}0.98 & 0.22 & 0.80 & 0.68 & 0.85\end{array}$

[061] Sugar, molasses and honey

[062] Sugar confectionery

[071] Coffee and coffee substitutes

[072] Cocoa

[073] Chocolate, food preparations with cocoa, n.e.s.

[074] Tea and mate

[075] Spices

$\begin{array}{llllll}0.94 & 0.64 & 0.84 & 0.80 & 0.91 & 0.80\end{array}$

$\begin{array}{llllll}0.90 & 0.91 & 0.89 & 0.81 & 0.94 & 0.95\end{array}$

$\begin{array}{llllll}- & - & - & - & - & - \\ 0.48 & 0.55 & 0.72 & 0.64 & 0.88 & 0.77\end{array}$

$\begin{array}{llllll}- & - & - & - & - & - \\ 0.88 & 0.98 & 0.98 & 0.83 & 0.97 & 0.98\end{array}$

$\begin{array}{llllll}0.99 & 0.96 & 0.99 & 0.97 & 1.00 & 1.00\end{array}$

$\begin{array}{llllll}- & - & - & - & - & - \\ 0.84 & 0.98 & 0.97 & 0.92 & 0.97 & 0.96\end{array}$

$\begin{array}{llllll}0.84 & 0.98 & 0.97 & 0.92 & 0.97 & 0.96 \\ - & - & - & - & - & -\end{array}$

$\begin{array}{llllll}0.97 & 0.93 & 0.99 & 0.96 & 0.99 & 0.98\end{array}$

$\begin{array}{llllll}0.43 & 0.38 & 0.34 & 0.33 & 0.35 & 0.25\end{array}$

[081] Feeding stuff for animals (no unmilled

0.04 cereals)

[091] Margarine and shortening

$\begin{array}{lllll}0.44 & 0.57 & 0.53 & 0.42 & 0.44\end{array}$

$\begin{array}{llllll}1.00 & 0.96 & 1.00 & 0.98 & 1.00 & 1.00\end{array}$ 
[098] Edible products and preparations, n.e.s.

[111] Non-alcoholic beverages, n.e.s.

[112] Alcoholic beverages

[121] Tobacco, unmanufactured; tobacco refuse

[122] Tobacco, manufactured

\begin{tabular}{llllll}
- & - & - & - & - & - \\
0.92 & 0.90 & 0.89 & 0.91 & 0.92 & 0.86 \\
- & - & - & - & - & - \\
0.91 & 0.57 & 0.76 & 0.86 & 0.65 & 0.28 \\
- & - & - & - & - & - \\
0.95 & 0.91 & 0.90 & 0.94 & 0.87 & 0.86 \\
- & - & - & - & - & - \\
0.96 & 1.00 & 0.99 & 0.97 & 1.00 & 1.00 \\
0.53 & - & 0.62 & 0.18 & 0.45 & 0.35 \\
& 0.69 & & & & \\
0.96 & 0.93 & 0.77 & 0.88 & 0.94 & 0.90 \\
& & & & & \\
- & - & - & - & 0.32 & 0.87 \\
0.93 & 0.79 & 0.15 & 0.92 & & \\
- & - & - & - & - & - \\
0.99 & 0.80 & 0.99 & 0.90 & 1.00 & 1.00 \\
- & - & - & - & - & - \\
0.97 & 0.95 & 0.39 & 0.79 & 0.98 & 0.99 \\
- & - & - & - & - & - \\
0.99 & 0.94 & 1.00 & 0.94 & 0.96 & 0.91 \\
- & - & - & - & - & - \\
0.99 & 0.91 & 0.99 & 0.94 & 0.99 & 0.98 \\
- & - & - & - & - & - \\
0.59 & 0.54 & 0.66 & 0.57 & 0.59 & 0.62 \\
\hline & & & & & \\
\hline
\end{tabular}

[222] Oil seeds and oleaginous fruits (excluding flour)

[223] Oil seeds \& oleaginous fruits (incl. flour, n.e.s.)

[411] Animals oils and fats

[421] Fixed vegetable fats \& oils, crude, refined, fractio.

[422] Fixed vegetable fats \& oils, crude, refined, fract.

[431] Animal or veg. oils \& fats, processed, n.e.s.; mixt.

Total 46 food product groups (SITC $0+1+22+4$ )

Source: Own analysis based on UNCTAD (2019)

A breakdown of the share of Nigeria's top five destination partners show that the country's food exports to the Netherlands (\$108 million, 23.4\%), Ghana ( $\$ 55$ million, 12\%), Niger (\$30 million, 6.5\%), Cote d'Ivoire (\$29.3 million, 6.3\%), and Malaysia (\$23.5 million, 5.1\%) accounted for over $53 \%$ of total national food exports in 2017. Also, Nigeria's top five food import partners shows that Brazil ( $\$ 635$ million, 33.3\%), China ( $\$ 166$ million, 8.68\%), France (\$165 million, 8.65\%), USA (\$124 million, 6.5\%) and Germany (\$115 million, 6\%) accounted for over $63 \%$ of total national food imports in 2017 (WITS, 2019).

The share of the ten mostly exported food products (\% of total food exports) in Nigeria increased from $78.9 \%$ in 2012 to $94.9 \%$ in 2016 and then declined to $92.3 \%$ in 2017 . Also, the top five export product groups, SITC 072 (cocoa), SITC 057 (fruits and nuts), SITC 222 (oil seeds and oleaginous), SITC 122 (tobacco, manufactured), and SITC 036 (crustaceans, molluscs, etc) jointly accounted for over $78 \%$ of the total Nigerian food exports in 2017 (Table 1). Similarly, NBS (2019) report shows that the primary agricultural products exported in 2018 were cocoa products, sesamum seeds (whether or not broken) and cashew nuts (in shell).

On the other hand, the share of the ten mostly imported food products $(\%$ of total food imports) rose from $57.8 \%$ in 2010 to $83 \%$ in 2017. Also, the top 5 food products, SITC 041 (wheat), SITC 098 (edible products), SITC 034 (fish, fresh), SITC 061 (sugar, molasses/honey), and SITC 022 (milk and cream) jointly accounted for over $70 \%$ of the total food imports in 2017. This signifies that Nigeria's food trade has been concentrated in a few products (Table 1 ). 
A critical look at the individual agri-food product groups suggests that Nigeria recorded positive TBI only in few products: SITC 036 (crustaceans, molluscs and aquatic invertebrates); SITC 057; SITC 072; SITC 075 (spices); SITC 122 (tobacco, manufactured); and SITC 222/SITC 223. This suggests that Nigeria has been competitive and specialised in only few food product groups. On the other hand, the country substantially recorded negative TBI in many food product groups between 2012 and 2017 (Table 2). It suggests that the country's agricultural policies may not have drastically improved agricultural production.

Market opportunities for food producers are increasingly dynamic induced by income changes, rapid population growth, and dietary diversification. Notwithstanding, Nigeria highly exports unprocessed agri-food products (mainly fresh tropical commodities), such as cocoa beans, oilseeds, fruits and nuts, and crustaceans. Because of the natural conditions, as postulated by dependency and traditional trade theories, some of these food products (Table 1) are highly demanded in continents that cannot produce them in large quantities. Also, few wealthy consumers' insatiable demands for processed food products from abroad may have driven food imports surged.

Arguably, substantial adverse TBI may have had implications for food security in Nigeria, although food imports may fill domestic gaps. However, in a country like Nigeria, the majority of the inhabitants live in poverty (UNDP, 2018), and most rural dwellers mainly eat what they produce, having negative TBI in many food products should be a source of concern for policy makers and implementers.

\subsection{Dimensions of Food Security in Nigeria}

In 2018, more than 113 million people in 53 countries witnessed acute hunger requiring urgent food, nutrition and livelihoods support. Similarly, the worst food crises in 2018, in order of severity, were: Yemen, DR Congo, Afghanistan, Ethiopia, Syria, Sudan, South Sudan and northern Nigeria. These eight nations accounted for $2 / 3$ of the total number of people facing acute food insecurity, approximately 72 million people. Sadly, northeast Nigeria is expected to remain among the world's most severe food crises in 2019 (FSIN, 2019).

The GFSI in the 113 countries increased from 56.9 to 58.7 between 2013 and 2016 and then decreased to 57.9 in 2017 before increasing to 58.4 in 2018 (Table 3). The improvement has been driven by infrastructure development, production capacity, as well as relatively stable global food prices across the countries (EIU, 2018). Even though GFSI in SSA and the world improved, Nigeria recorded deteriorating scores, scoring less than 40 points between 2012 and 2018. It suggests that Nigeria has faced severe food security issues in food indicators, especially in food affordability index (Table 3). This finding is in line with the studies by Akerle et al. (2013) who find out that the majority of households in South-West Nigeria were food insecure, they require an average of about $440 \mathrm{kcal}$ to achieve food security level of 2,550 kcal.

Table 3: Global food security index (score) in Nigeria, SSA and the World, 2012-2018

Published by ECSDEV, Via dei Fiori, 34, 00172, Rome, Italy

http://ecsdev.org 


\begin{tabular}{|c|c|c|c|c|c|c|c|}
\hline Indicator/year & 2012 & 2013 & 2014 & 2015 & 2016 & 2017 & 2018 \\
\hline \multicolumn{8}{|l|}{ Overall GFI } \\
\hline Nigeria & 37.7 & 37.3 & 37.6 & 37.9 & 39.6 & 39.1 & 38.0 \\
\hline SSA & 37.8 & 37.2 & 38.1 & 39.4 & 39.5 & 38.3 & 38.6 \\
\hline World & 56.9 & 56.6 & 57.3 & 58.2 & 58.7 & 57.9 & 58.4 \\
\hline \multicolumn{8}{|l|}{ Food affordability } \\
\hline Nigeria & 26.9 & 23.4 & 27.1 & 27.1 & 26.9 & 26.6 & 26.5 \\
\hline SSA & 33.0 & 31.2 & 31.8 & 32.3 & 32.1 & 29.8 & 29.6 \\
\hline World & 56.5 & 56.0 & 56.8 & 57.4 & 57.6 & 56.2 & 56.3 \\
\hline \multicolumn{8}{|l|}{ Food accessibility } \\
\hline Nigeria & 43.5 & 45.8 & 42.5 & 43.1 & 47.2 & 46.4 & 44.4 \\
\hline SSA & 43.1 & 43.4 & 44.6 & 46.7 & 47.1 & 46.1 & 47.2 \\
\hline World & 57.2 & 56.8 & 57.5 & 58.8 & 59.9 & 59.1 & 60.3 \\
\hline SSA & 43.1 & 43.4 & 44.6 & 46.7 & 47.1 & 46.1 & 47.2 \\
\hline \multicolumn{8}{|c|}{ Food quality and safety } \\
\hline Nigeria & 48.5 & 48.7 & 50.3 & 50.5 & 50.5 & 50.5 & 49.4 \\
\hline SSA & 34.9 & 35.3 & 36.3 & 37.3 & 37.2 & 37.8 & 37.6 \\
\hline World & 57.3 & 57.3 & 58.0 & 58.6 & 58.5 & 58.7 & 58.2 \\
\hline
\end{tabular}

Source: Compiled from EIU, 2018. Note: Score 0-100 (where 100=best)

\subsubsection{Food availability}

Food availability means that food must be enough and consistently available for consumption. The stock, production and the capacity to import or through food aid are the drivers of food availability. Although the average value of food production (const. 2004-2006 I\$/cap, 3-year average) in Nigeria increased from 198 between 2011 and 2013 to 211 between 2014 and 2016 (FAO, 2019), the index of food availability in the country declined from 47.2/100 to 44.4/100 between 2016 and 2018 (Table 4). Agricultural production in Nigeria has largely been on a subsistence level, carried out by smallholder farmers that lack the know-how and modern inputs. Consequently, food production has not kept pace with population growth, resulting in over-reliant on food imports (Table 1), decreasing national food self-sufficiency (World Food Programme, 2019).

Table 4: Indicators of food availability index (score) in Nigeria, 2012-2018.

\begin{tabular}{|c|c|c|c|c|c|c|c|c|c|}
\hline Indicators/year & 2012 & 2013 & 2014 & 2015 & 2016 & 2017 & 2018 & SSA2018 & World2018 \\
\hline Availability & 43.5 & 45.8 & 42.5 & 43.1 & 47.2 & 46.4 & 44.4 & 47.2 & 56.8 \\
\hline $\begin{array}{l}\text {-Sufficiency of } \\
\text { supply }\end{array}$ & 37.6 & 50.3 & 37.0 & 37.5 & 35.4 & 35.8 & 35.8 & 34.3 & $\mathrm{n} / \mathrm{a}$ \\
\hline $\begin{array}{l}\text {--Average food } \\
\text { supply } \\
\text { (kcal/capita/day) }\end{array}$ & 51.3 & 50.4 & 50.4 & 51.2 & 48.3 & 48.9 & 48.9 & $\mathrm{n} / \mathrm{a}$ & $\mathrm{n} / \mathrm{a}$ \\
\hline $\begin{array}{l}\text { Public } \\
\text { expenditure on } \\
\text { agric. R\&D }\end{array}$ & 0.0 & 0.0 & 0.0 & 0.0 & 0.0 & 0.0 & 0.0 & 10.7 & 15.6 \\
\hline $\begin{array}{l}-\quad \text { Agricultural } \\
\text { infrastructure }\end{array}$ & 41.7 & 41.7 & 41.7 & 32.4 & 32.4 & 32.4 & 32.4 & 39.1 & 57.8 \\
\hline $\begin{array}{l}--\quad \text { Road } \\
\text { infrastructure }\end{array}$ & 25.0 & 25.0 & 25.0 & 25.0 & 25.0 & 25.0 & 25.0 & $\mathrm{n} / \mathrm{a}$ & $\mathrm{n} / \mathrm{a}$ \\
\hline
\end{tabular}




\begin{tabular}{llllllllll}
$-\quad$ Volatility of & 93.7 & 93.7 & 95.1 & 95.3 & 94.7 & 94.3 & 95.9 & 84.0 & 86.4 \\
$\begin{array}{l}\text { agric. production } \\
\text { Political }\end{array}$ & 27.8 & 27.8 & 27.8 & 27.8 & 38.9 & 47.1 & 47.1 & 34.5 & 46.8 \\
$\begin{array}{l}\text { stability risk } \\
\text { - Corruption }\end{array}$ & 0.0 & 0.0 & 0.0 & 0.0 & 25.0 & 25.0 & 0.0 & 22.3 & 37.6 \\
- Urban & 78.7 & 71.3 & 67.9 & 58.1 & 68.7 & 51.7 & 54.0 & 72.9 & 76.9 \\
$\begin{array}{l}\text { absorption } \\
\text { capacity }\end{array}$ & & & & & & & & & \\
- - Food loss & 49.7 & 49.7 & 49.7 & 70.0 & 70.6 & 70.6 & 70.6 & 72.9 & 84.9 \\
\hline
\end{tabular}

Source: Compiled from EIU, 2018. Note: Score 0-100 (where 100=best); $n / a=$ data not available

The findings suggest that food availability in Nigeria has been higher than affordability, but the country's performance has been below SSA and the global averages in almost all the availability indicators (Table 3). A critical look at the availability index suggests that public expenditure on agricultural R\&D, institutional corruption, infrastructure, urban absorption capacity, political stability risk, supply (average food supply (kcal/capita/day)) and food loss have contributed to food insecurity in Nigeria. The above challenges may have partially nullified Nigeria's capacity to increase food production and its availability to consumers in the country (Table 4). Similarly, Verma et al. (2019) confirm that there are hardly public investments in agricultural research and development (R\&D) in Nigeria.

Owing to sparse road networks and agriculture infrastructure in Nigeria, farmers find it difficult to either move inputs to the farms or output from the farms to markets/homes for sales/household consumption within the shortest time. Studies by Verma et al. (2019), and Plaisier et al. (2019) suggest that a substantial portion of food produced, especially perishable products are lost in the production value chain system because of poor infrastructure, preservation and storage facilities.

The political stability index (-2.5 weak; 2.5 strong) shows that Nigeria recorded -1.94 index points in 2017. Similarly, fragile state index (0 (low) - 120 (high) ) shows that Nigeria recorded 99.9 index points in 2018 (TheGlobalEconomy.com). These indices suggest that Nigeria has experienced low political stability and high fragility, posing a major threat to the attainment of SDG2 of ending hunger, ensuring food security and sustainable agriculture in the country. Also, studies by FSIN (2019) shows that acute malnutrition significantly worsened in north-eastern Nigeria between 2017 and 2018 due to political instability risk. In the 16 states of northern Nigeria and the FCT, the number of people in crisis and emergency reduced by $40 \%$ between June-August 2017 . At the peak of the season, 3 million people were acutely food insecure in the three north-eastern states where the Boko Haram's terrorist group largely destroyed agricultural production, trade, and livelihoods.

\subsubsection{Food affordability}

Without the means to have access to the food, people will go to bed with an empty stomach even if food is available. Thus, the relevance of food affordability as an indicator of food security cannot be overemphasized. Consumers may have access to food through production by the households, aid, borrowings, or purchases, especially when prices are relatively low, and consumers have reasonable incomes to afford it. The number of undernourished people in Nigeria steadily rose from 9 million (6\%) between 2007 and 
2009 to 21.5 million (11.5\%) between 2015 and 2017. Arguably, those people did not have sufficient access to food that would provide them with enough dietary energy necessary to maintain a normal, active, and healthy life. Sadly, the number of the adult population in the prevalence of severe food insecurity in Nigeria rose from 40.7 million $(22.4 \%)$ to 46.1 million (24.8\%) between 2014 and 2017 (Figure 1).

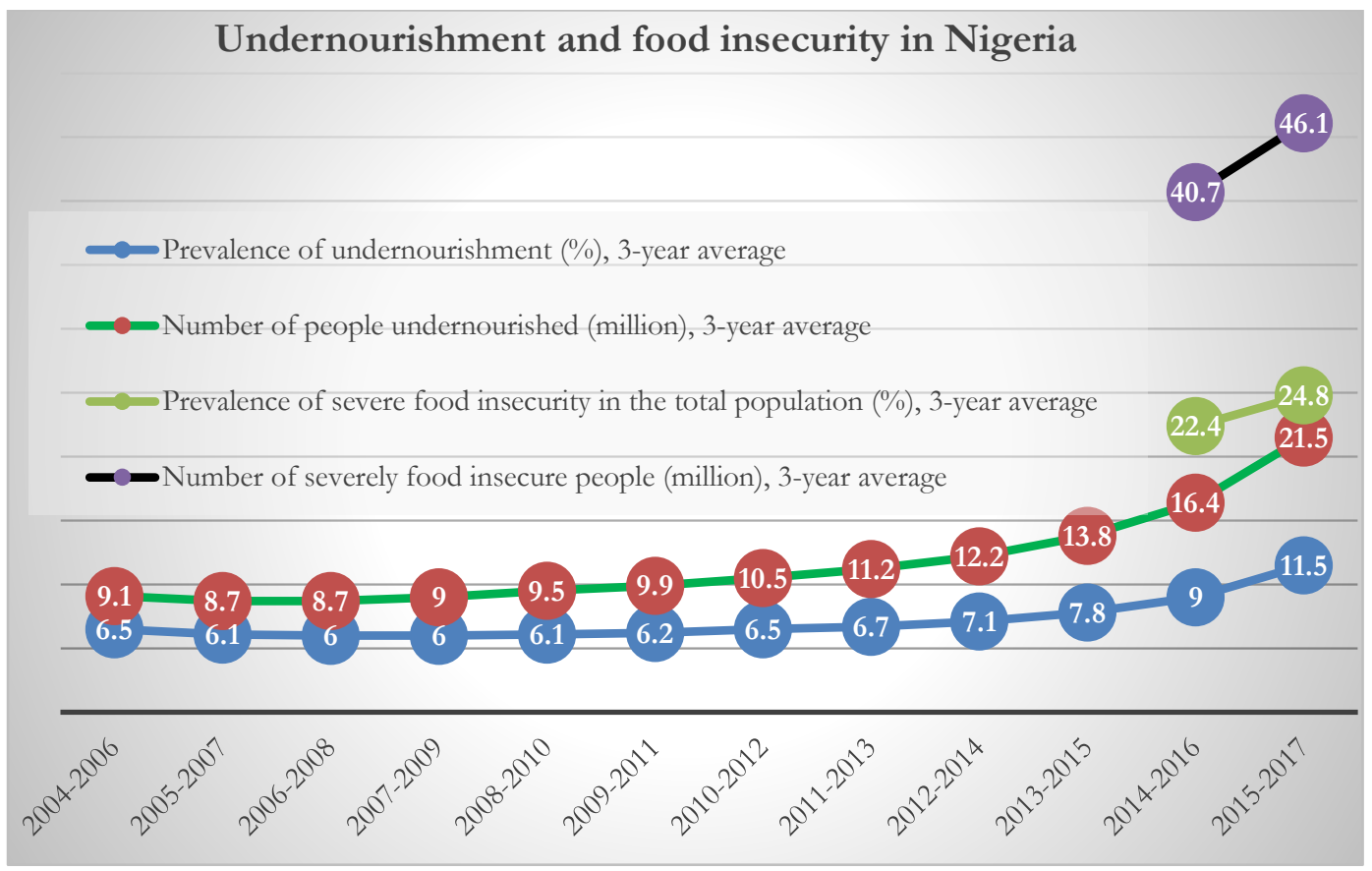

Figure 1: Undernourishment and food insecurity (millions, \%) in Nigeria

Source: Own analysis based on FAO (2019)

Table 4 shows that food affordability index is the most challenge that Nigeria must be urgently addressed in Nigeria for the country to improve its food security status. The country performed below SSA and global averages (Table 3). A breakdown of affordability indicators shows that the proportion of Nigerians under the global poverty line $(\$ 3.20 /$ day 2011 PPP), and low GDP per capita (US\$ PPP) have been among the critical issues of food security in the country. Arguably, poverty may have been explained why the index of food consumption (\% of household expenditure) in the country has been weak and below the SSA and global averages. FAO (2017) stresses that high poverty affects households whose primary source of income is agriculture in Nigeria. Similarly, Akerele et al. (2013) find out that the household size, especially those with a high number of dependants, hurt food security in South-West Nigeria.

The unemployment rate increased in Nigeria rapidly rose from $10.6 \%$ in 2012 to $22.6 \%$ in 2018. Even though GDP per capita (current 2011, US\$ PPP) in Nigeria slightly rose from $\$ 5,526$ in 2012 to $\$ 6,027$ in 2018 (IMF, 2019), it is still far from drastically reducing the poverty rate and improving food affordability index in the country. Similarly, a lack of 
farmers' access to financing agricultural related activities suggests having impeded food production to meet the domestic demand in the country.

Table 5: Indicators of food affordability index (score) in Nigeria, 2012-2018

\begin{tabular}{|c|c|c|c|c|c|c|c|c|c|}
\hline Indicators/year & 2012 & 2013 & 2014 & 2015 & 2016 & 2017 & 2018 & SSA2018 & World2018 \\
\hline Affordability & 26.9 & 23.4 & 27.1 & 27.1 & 26.9 & 26.6 & 26.5 & 38.6 & 56.3 \\
\hline $\begin{array}{l}\text { - } r \text { Food } \\
\text { consumption }(\% \\
\text { of household } \\
\text { expenditure) }\end{array}$ & 26.5 & 26.5 & 26.5 & 26.4 & 26.4 & 12.9 & 12.9 & 33.8 & 55.6 \\
\hline $\begin{array}{l}-\quad \% \quad \text { of } \\
\text { population under } \\
\text { global poverty } \\
\text { line }\end{array}$ & 47.7 & 30.5 & 30.5 & 30.5 & 30.5 & 30.5 & 30.5 & 42.1 & 80.9 \\
\hline $\begin{array}{l}\text { - GDP per capita } \\
\text { (US\$ PPP) }\end{array}$ & 3.6 & 3.8 & 3.9 & 4.1 & 4.2 & 4.0 & 4.0 & 2.3 & 16.7 \\
\hline $\begin{array}{ll} & \text { Agricultural } \\
\text { import } & \text { tariffs } \\
(\%) & \end{array}$ & 76.8 & 76.9 & 78.2 & 78.0 & 75.6 & 75.3 & 74.3 & 71.7 & 75.4 \\
\hline $\begin{array}{l}\text { Presence of } \\
\text { food safety net } \\
\text { programmes }\end{array}$ & 0.0 & 0.0 & 25.0 & 25.0 & 25.0 & 25.0 & 25.0 & 23.3 & 65.5 \\
\hline $\begin{array}{l}\text { Access to } \\
\text { financing for } \\
\text { farmers }\end{array}$ & 25.0 & 25.0 & 25.0 & 25.0 & 25.0 & 50.0 & 50.0 & 23.3 & 62.6 \\
\hline
\end{tabular}

Source: Compiled from EIU, 2018. Note: Score 0-100 (where 100=best)

In SSA countries, such as Nigeria where about $50 \%$ of the populations lived in rural areas in 2018 (UN DESA 2019), and they mostly eat what they produced, ensuring maximum food production and stabilising prices are critical ingredients in reducing food insecurity. Also, reports (NBS, 2019; FAO, 2019; FSIN, 2019) suggest that production shortfalls drove high food prices in Nigeria, insecurity and subsidy cuts have had implication for food security in the country.

\subsubsection{Food quality and safety}

Globally, ensuring food quality and safety has been identified as among the major obstacles to agri-food trade (Verter, 2016) and food security in Nigeria and SSA countries (Table 6), where producers lack knowledge on the need for global standards and best practices. As shown in Table 6, the overall food quality and safety index in Nigeria reduced from 50.5 to 49.4 between 2017 and 2018. The index was also below the global standards or average, suggesting that food quality and safety in Nigeria has been low. Although the country performed good food safety index, indicators such as diet diversification, micronutrient availability, and protein quality have remained the significant constraints to food quality and safety attainment and food security in general.

Table 6: Indicators of food quality and safety index (score) in Nigeria, 2012-2018

$\begin{array}{lllllllll}2012 & 2013 & 2014 & 2015 & 2016 & 2017 & 2018 & \text { SSA2018 } & \text { World2018 }\end{array}$

Indicators/year 


\begin{tabular}{|c|c|c|c|c|c|c|c|c|c|}
\hline $\begin{array}{l}\text { Quality and } \\
\text { Safety }\end{array}$ & 48.5 & 48.7 & 50.3 & 50.5 & 50.5 & 50.5 & 49.4 & $\mathrm{n} / \mathrm{a}$ & 58.2 \\
\hline Diet & 29.8 & 29.8 & 26.8 & 26.8 & 25.0 & 25.0 & 24.1 & 33.1 & 56.0 \\
\hline diversification & & & & & & & & & \\
\hline $\begin{array}{l}\text { - Micronutrient } \\
\text { availability }\end{array}$ & 44.3 & 44.3 & 44.3 & 44.3 & 44.3 & 44.3 & 44.3 & 30.9 & $\mathrm{n} / \mathrm{a}$ \\
\hline - Protein quality & 38.1 & 38.7 & 38.8 & 39.3 & 40.5 & 40.5 & 36.8 & 27.0 & 47.3 \\
\hline - Food safety & 50.7 & 51.0 & 63.9 & 64.2 & 64.6 & 64.6 & 64.6 & 41.3 & 80.3 \\
\hline $\begin{array}{l}--\% \text { of pop. with } \\
\text { access to potable } \\
\text { water }\end{array}$ & 43.3 & 44.1 & 44.8 & 45.6 & 46.5 & 46.5 & 46.5 & $\mathrm{n} / \mathrm{a}$ & $\mathrm{n} / \mathrm{a}$ \\
\hline
\end{tabular}

Source: Compiled from EIU, 2018. Note: Score 0-100 (where 100=best)

Diet diversification index recorded low and declined from 29.8 in 2012 to 24.1 in 2018 (Table 6), suggesting that variety of food consumed by Nigerian households hardly diverse regarding nutrient intakes (inadequate intake) within the period under review. This may have had adverse effects on the micronutrients supply or availability for consumers. Similarly, Ajani (2010) finds out that dietary diversity has been poor in Nigeria and suggests policy to improve nutritional status for dietary diversity. Ogundari (2017) shows that household diet diversification is driven by their income, level of education and household size in Nigeria.

\subsubsection{Natural resources and resilience}

Resilience to natural resource and climate shocks pose long term threats to food systems across countries (EIU, 2018). The government of Nigeria launched the National Agricultural Resilience Framework (NARF) in 2014 to mitigate climate shocks and stresses occasioned by climate change (FAO, 2017). Notwithstanding, the humanitarian situation in northern Nigeria has been driven mainly by three factors: conflict/insecurity occasioned by Boko Haram and Pastoralists, and climate shocks (FAO et al., 2018), and economic meltdown, mutually reinforcing combination of all these drivers have contributed in worsening food crises in Nigeria (FSIN, 2019).

Displacement has disrupted livelihoods in the affected areas (FSIN, 2019). Consequently, food production in northeast Nigeria drastically dropped over the last five years as producers are often unable to reach their farmlands due to insecurity caused by conflict (World Food Programme, 2019). The lingering conflicts have undermined access to income-earning opportunities and put pressure on resources, with dire implications for the food security of displaced populations and host communities (FSIN, 2019).

The findings of FSI suggest that the overall natural resources and resilience in Nigeria were moderate (58.7), but below the world average, ranked 68/113 countries. Although Nigeria performed very good in grassland (100), storm severity (96.3), and water (70.1) in 2018, other indicators, such as oceans (27.9), demographic stresses (30.2), forest change (35.4), drought (32.3), urbanisation (25.4), population growth (31.8), and marine biodiversity (15.2) suggest to have posed a threat to food security attainment in the country. Similarly, FSI findings suggest that flooding (27.7), food import dependency (25.3), disaster risk (42.9), and forest change (35.4) have also contributed to food insecurity in Nigeria (Table 7). Available data from FAO (2019) shows that the forest area (\% of land area) in Nigeria 
steadily decreased from $18.92 \%$ to $7.23 \%$ between 1990 and 2016 due to deforestation and other factors.

Table 7: Indicators of natural resources and resilience index (score, rank) in Nigeria, 2017-2018

\begin{tabular}{|c|c|c|c|c|}
\hline Indicators & Score2017 & Score2018 & Rank2018 & $\begin{array}{l}\text { World } \\
\text { score } \\
2018\end{array}$ \\
\hline Natural Resources \& Resilience- overall & 61.0 & 58.7 & $=68$ & 62.2 \\
\hline -Exposure & 62.5 & 62.5 & $=67$ & 63.3 \\
\hline -- Temperature rise & 74.8 & 74.8 & 59 & 70.4 \\
\hline -- Drought & 32.3 & 32.3 & 103 & 64.9 \\
\hline -- Flooding & 27.7 & 27.7 & 85 & 39.5 \\
\hline -- Storm severity (AAL) & 96.3 & 96.3 & 24 & 56.4 \\
\hline -Water & 70.1 & 70.1 & 23 & 55.0 \\
\hline - Land & 81.1 & 81.1 & $=72$ & 82.9 \\
\hline -- Soil erosion/organic matter & 90.0 & 90.0 & 40 & 86.2 \\
\hline -- Grassland & 100.0 & 100.0 & 1 & 97.6 \\
\hline -- Forest change & 35.4 & 35.4 & 107 & 58.6 \\
\hline - Oceans & 41.3 & 27.9 & 98 & 59.7 \\
\hline -- Marine biodiversity & 46.3 & 15.2 & 96 & 53.0 \\
\hline -- Marine protected areas & 0.3 & 0.0 & 109 & 33.7 \\
\hline - Sensitivity & 47.6 & 48.0 & $=80$ & 54.0 \\
\hline -- Food import dependency & 23.4 & 25.3 & 49 & 24.7 \\
\hline -- Dependence on natural capital & 96.0 & 95.0 & 68 & 88.8 \\
\hline -- Disaster risk management & 42.9 & 42.9 & 77 & 57.6 \\
\hline - Adaptive capacity & 66.7 & 66.7 & $=42$ & 58.1 \\
\hline -- Early warning measures/climate smart ag & 50.0 & 50.0 & 40 & 46.0 \\
\hline $\begin{array}{l}\text {-- National agricultural risk management } \\
\text { system }\end{array}$ & 83.3 & 83.3 & 36 & 70.2 \\
\hline - Demographic stresses & 38.8 & 30.2 & 96 & 58.4 \\
\hline -- Population growth (2016-21) & 44.6 & 31.8 & 95 & 57.8 \\
\hline -- Urbanisation (2016-21) & 21.5 & 25.4 & 98 & 60.2 \\
\hline
\end{tabular}

Source: Compiled from EIU, 2018. Rank out of 113 countries (where $1=$ best), ' $=$ ' before the rank indicates a tie

Although the Malthusian theory of population and food supply may have been invalid in advanced economies since the advancement of technology and slow in population increment, the theory may still be valid in some SSA countries like Nigeria where population growth has been more than 2.5\% (UN DESA, 2019), which has not kept pace with food production (World Food Programme, 2019). This is coupled with an alarming poverty rate, low HDI (0.532) in 2017 (UNDP, 2018).

Although urbanisation index improved from 21.5 to 35.4 between 2017 and 2018, it still appears to be a significant obstacle to food security in Nigeria (Table 7). Arguably, urbanisation issues are induced and population growth, rural-urban migration, lack of job opportunities and infrastructure in the country. Also, findings by Omonona \& Agoi (2007) and Lamidi (2019) suggest that food insecurity incidence escalated in unemployed people with large household size in Nigeria. The country substantially recorded negative trade 
balance and TBI in agri-food products (Table 1), suggesting that it is a food importdependent country.

\section{Conclusions}

This paper investigates the dynamics of trade in food products and food security indicators in Nigeria. The findings show that Nigeria markedly recorded an adverse TBI in total agri-food products and many food product groups. Remarkably, the five mostly exported and five mostly imported food products accounted for $78 \%$ and $70 \%$ of total food exports and imports respectively in 2017. The study also reveals that Nigeria has been grossly food insecure driven by indicators, such as agricultural infrastructure deficit, rapid population growth, poverty, corruption, inadequate government support to farmers as well as the absence of safety net programmes. The Nigerian government and other stakeholders should holistically invest and implement agricultural policies to reverse over-reliant on food imports, improve food security indicators and earnings in many food products. Further studies should conduct primary research to investigate the state of food security/insecurity in Nigeria.

\section{References}

Adebayo, P. F., \& Ojo, E. O. (2012). Food security in Nigeria: An overview. European Journal of Sustainable Development, 1(2), 199-221.

Akerele, D., Momoh, S., Aromolaran, A. B., Oguntona, C. R., \& Shittu, A. M. (2013). Food insecurity and coping strategies in South-West Nigeria. Food Security, 5(3), 407-414.

de Sousa, L. R. M., Saint-Ville, A., Samayoa-Figueroa, L., \& Melgar-Quiñonez, H. (2019). Changes in food security in Latin America from 2014 to 2017. Food Security, 1-11.

Economist Intelligence Unit (EIU). (2018). Global food security index 2018: Building resilience in the face of rising food-security risks. EIU. Retrieved from https://bit.ly/2sgHSq1 (accessed on 17 May 2019).

FAO. (2017). Regional overview of food security and nutrition in Africa 2016. The challenges of building resilience to shocks and stresses. Accra: FAO.

FAO. (2018). Food outlook- biannual report on global food markets - November 2018. Rome: FAO.

FAO. (2019). FAOSTAT database. Retrieved from http://bit.ly/NmQzZf (accessed on 15 May 2019).

FAO, IFAD, UNICEF, WFP and WHO. (2018). The State of food security and nutrition in the world 2018: Building climate resilience for food security and nutrition. Rome: FAO.

Federal Ministry of Agriculture and Rural Development (FMARD). (2016). The agriculture promotion policy (2016 - 2020): Building on the successes of the ATA, closing key gaps. Abuja: FMARD.

Food Security Information Network (FSIN). (2019). Global report on food crises 2019. FSIN. Retrieved from http://fsinplatform.org/ (accessed on 20 May 2019).

IMF (2019). World economic outlook database, April 2019. Retrieved from https://bit.ly/2F0guUc (accessed 2 June 2019).

Lamidi, E. O. (2019). Household composition and experiences of food insecurity in Nigeria: the role of social capital, education, and time use. Food Security, 11(1), 201-218.

Mary, S. (2019). Hungry for free trade? Food trade and extreme hunger in developing countries. Food Security, 11 (2), 461-477.

Ministry of Budget \& National Planning (MBNP). (2017). Economic recovery \& growth plan 2017-2020. Abuja: MBNP.

National Bureau of Statistics (NBS). (2019). Foreign trade in goods statistics (Q4 2018). Abuja: NBS.

Ogundari, K. (2017). Categorizing households into different food security states in Nigeria: the socioeconomic and demographic determinants. Agricultural and Food Economics, 5, 8. 
Omonoma, B., \& Agoi, G. (2007). An analysis of food security situation among Nigerian urban households: evidence from Lagos State, Nigeria. Journal of Central European Agriculture, 8(3), 307-406.

Perez-Escamilla, R., Gubert, M. B., Rogers, B., \& Hromi-Fiedler, A. (2017). Food security measurement and governance: Assessment of the usefulness of diverse food insecurity indicators for policy makers. Global Food Security, 14, 96-104.

Plaisier, C., Sibomana, M., van der Waal, J., Clercx, L., van Wagenberg, C., \& Dijkxhoorn, Y. (2019). Approach for designing context-specific, locally owned interventions to reduce postharvest losses: Case study on tomato value chains in Nigeria. Sustainability, 11(1), 247.

Singh, I. (2014). Linkages between agricultural trade liberalization and food security: Evidence from India and policy challenges. International Journal of Economic Issues, 7(2), 231-257.

TheGlobalEconomy.com. Database. Retrieved from https://bit.ly/2K5iRJH (accessed on 11 June 2019).

UNCTAD. (2019). World statistical database. Retrieved from https://bit.ly/21GbfKX (accessed on 3 June 2019).

United Nations, Department of Economic and Social Affairs (UN DESA). (2018). World urbanization prospects: The 2018 Revision, Online Edition. Retrieved from https://bit.ly/2IJfzba (accessed on 4 June 2019).

United Nations Development Programme (UNDP). (2018). Human development indices and indicators, 2018 Statistical Update. New York: UNDP.

Verma, M., Plaisier, C., van Wagenberg, C., \& Achterbosch, T. (2019). A Systems Approach to Food Loss and Solutions: Understanding Practices, Causes, and Indicators. Sustainability, 11(3), 579.

Verter, N. (2016). Analysis of external influences on agricultural performance in Nigeria. Acta Universitatis Agriculturae et Silviculturae Mendelianae Brunensis, 64(5), 1805-1821.

World Bank. (2019). World development indicators. Retrieved from https://data.worldbank.org/indicator/sl.agr.empl.zs (accessed on 8 June 2019).

World Food Programme. (2019). Draft Nigeria country strategic plan (2019-2022). No. WFP/EB.1/2019/6A/8/DRAFT. Retrieved from https://bit.ly/2WZO5HY (accessed on 9 June 2019).

World Food Summit. (1996). Rome declaration on world food security and world food summit plan of action. Rome: FAO.

World Integrated Trade Solution (WITS). (2019). Nigeria trade statistics. Retrieved from https://bit.ly/2WKPHS0 (accessed on 10 June 2019). 